\title{
Physicochemical and Biopharmaceutical Evaluation of Casiopeina III-Ea, a New Compound with Antineoplastic Activity
}

\author{
Nancy Vara-Gama ${ }^{2}$, Kenneth Rubio Carrasco ${ }^{1}$, Adrián Espinoza-Guillén ${ }^{2}$, Lena Ruiz-Azuara ${ }^{2}$, Inés \\ Fuentes-Noriega*1 \\ ${ }^{1}$ Department of Pharmacy, Building E, Faculty of Chemistry, National Autonomous University of Mexico, \\ Mexico, D.F. 04510, Mexico. \\ ${ }^{2}$ Department of Inorganic and Nuclear Chemistry, Building B, National Autonomous University of Mexico, \\ Mexico, D.F. 04510, Mexico.
}

*Corresponding author: Inés Fuentes-Noriega, email: ifuentes@unam.mx, Phone: 5556225283, cell Phone 5554096198.

Received November 19 $9^{\text {th }}, 2020$; Accepted March $2^{\text {nd }}, 2021$.

DOI: http://dx.doi.org/10.29356/jmcs.v65i3.1471

\begin{abstract}
In the present work, the physicochemical (pka, intrinsic solubility, Log D distribution coefficient) and biopharmaceutical characterization ( $\mathrm{IC}_{50}$ studies in MDCK cells) of Casiopeina III-Ea, a $\mathrm{Cu}$ (II) mixed chelate compound, was carried out. These parameters will tell us about the behaviour of Casiopeina III-Ea, as a new antineoplastic agent, in physiological media. This basic research of the Faculty of Chemistry of the UNAM, is directed towards the maturation of a technology, which consists of the pharmaceutical development of an antineoplastic copper coordination compound Casiopeina III-Ea.
\end{abstract}

Keywords: Casiopeina III-Ea; physicochemical properties; IC 50 ; MDCK cells; copper.

Resumen. En el presente trabajo se realizó la caracterización fisicoquímica (pka, solubilidad intrínseca, coeficiente de distribución Log D) y biofarmacéutica (estudios IC $_{50}$ en células MDCK) de Casiopeina III-Ea, un nuevo compuesto quelato mixto de cobre (II). Estos parámetros nos dirán mucho sobre el comportamiento de Casiopeina III-Ea, como un nuevo agente antineoplásico, en medios fisiológicos. Esta investigación básica de la Facultad de Química de la UNAM, está dirigida hacia la maduración de una tecnología, que consiste en el desarrollo farmacéutico de un compuesto de coordinación antineoplásico de cobre Casiopeina III-Ea.

Palabras clave: Casiopeina III-Ea; propiedades fisicoquímicas; $\mathrm{IC}_{50}$; células MDCK; cobre.

\section{Introduction}

The current research of drugs must be a satisfactory planning regarding the optimization of the molecules because they are going to be applied in human health to improve quality of life or to have a longer life expectancy. Within thousands of compounds that are developed, only a fraction has good absorption, distribution, metabolism, excretion, and toxicity (ADMET) / toxicology properties. By better understanding the properties-structure relationship, the necessary background is provided to interpret and apply the data for decisions to optimize in vivo pharmacokinetics, safety of biological tests, formulation, and therapy. Low solubility, chemical instability, low permeability can critically affect biological tests. 
Several novel compounds have been developed for the treatment of different types of cancer. Casiopeinas are a family of copper (II) coordination compounds with the general formula: $\mathrm{Cu}(\mathrm{N}-\mathrm{N})(\mathrm{O}-$ $\mathrm{O}) \mathrm{NO}_{3}$ or $\mathrm{Cu}(\mathrm{N}-\mathrm{N})(\mathrm{O}-\mathrm{N}) \mathrm{NO}_{3}$. These compounds were designed as a less toxic alternative to CisPlatinum since this drug is used in the treatment of various types of cancer. [1] Within the family of Casiopeinas with antineoplastic activity, Casiopeina III-Ea, is a copper complex that shows cytostatic, cytotoxic, genotoxic and antineoplastic activities through different mechanisms of action, both in vitro and in vivo models [2 - 11]. Casiopeina III-Ea was recently reported to have results that possesses strong antileukemic activity in vitro. [12]

In the present work, the physicochemical and biopharmaceutical characterization of Casiopeina III-Ea, a new antineoplastic, was carried out; it has been found to be very efficient in pediatric leukemia and was designed as a less toxic alternative to Cis-Platinum. This basic research of the Faculty of Chemistry of the UNAM, is directed towards the maturation of a technology, which consists of the pharmaceutical development of an antineoplastic copper coordination compound Casiopeina III-Ea. In order to know what its behaviour in physiological media will be, it is necessary to perform the evaluation of physicochemical tests such as: $\mathrm{pKa}$, intrinsic solubility, $\log \mathrm{D}$ distribution coefficient, and $\mathrm{IC}_{50}$ studies against $\mathrm{MDCK}$ cells, which will allow a better understanding of the ADMET process of the new molecule. In order to determine and quantify Casiopeina III-Ea in the different physicochemical and biopharmaceutical tests that were carried out, it was necessary to have precise and reliable methodologies. The analytical methodologies by HPLC-UV and spectrophotometry were validated taking into account some considerations and acceptance criteria of International guidelines for the Validation of Bioanalytical Methods, such as those established by the FDA, Guidance for Industry: Bioanalytical Method Validation (2001).

\section{Experimental}

\section{Reagents and equipment}

Casiopeina III-Ea (Fig. 1) was provided by the group of Dra. Lena Ruiz Azuara from the Department of Medicinal Inorganic Chemistry, Faculty of Chemistry, UNAM. Methanol grade HPLC X, deionized water Milli-Q, Monobasic sodium phosphate monohydrate J.T. Baker, anhydrous dibasic sodium phosphate J.T. Baker, HPLC grade water, ATCC fetal calf serum (FBS), ATCC dimethylsulfoxide (DMSO), Costar 96-well ELISA sterile plates, Gibco DMEM culture medium, Hank Gibco's solution, J.T. Baker ethyl alcohol, ELISA plate reader ELX800GDGR, sulforhodamine Aldrich Chemistry, Gibco Tris Base Solution, J.T. Baker Trichloroacetic Acid, ( $0.45 \mu \mathrm{m}$ Millipore GVPL type filters. ), hydrochloric acid ( J.T. Baker), phosphoric acid (J.T. Baker), sodium hydroxide ( Meyer ), and n-octyl alcohol ( 1-octanol ), ( Sigma Aldrich ). A Shimadzu UV-1601 brand UV-Visible spectrophotometer was used for sample analysis. Shimadzu HPLC with pump model LC10ADVP (Tokyo, Japan), Shimadzu model SPD10AD UV variable wave detector, model SIL10ADVP autosampler with a 20 to $100 \mu \mathrm{L}$ loop (Cotati, CA, USA), a Shimadzu brand controller system Model SCL10AVP (Tokyo, Japan), and a Shimadzu Class VP Version 5 Chromatographic Data Integrator 1999 were also used.

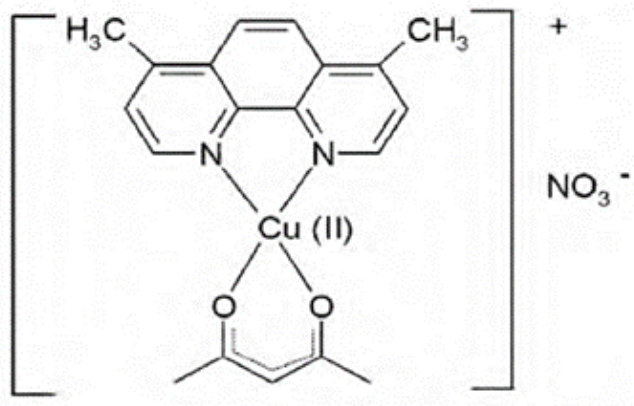

Fig. 1. Chemical structure of Casiopeina III-Ea. 


\section{Spectrophotometric method validation.}

\section{Linearity, repeatability and reproducibility for Casiopeina III-Ea}

For the validation of the spectrophotometric method, some criteria of the FDA, Guidance for Industry: Bioanalytical Method Validation (2001) were taken into account.[13] The parameters of linearity, repeatability and reproducibility were determined in each of the $\mathrm{pH}$ 's that were tested, using phosphate buffer solution as matrix.

From the Casiopeina III-Ea stock solution $(100 \mu \mathrm{g} / \mathrm{mL}), 3$ calibration curves were prepared in a range of 15 to $2.5 \mu \mathrm{g} / \mathrm{mL}$, they were taken to the gauging with phosphate buffer solutions at the following $\mathrm{pH}: 1.2$, 3.0, 4.6, 5.0, 6.8, 7.4 and 8.0. The procedure was repeated in 2 consecutive days. The samples were read in the UV-Visible spectrophotometer for $\mathrm{pKa}$ calculation, intrinsic solubility, and Log $\mathrm{D}$ to determine physicochemical properties of Casiopeina III-Ea.

\section{Determination of $\mathrm{pKa}$}

The determination of the $\mathrm{pKa}$ of Casiopeina III-Ea by the spectrophotometric technique required the preparation of phosphate buffer solutions at different $\mathrm{pH}$ values, to promote ionization in such a way that the absorptive properties of the species generated were modified.

With the data obtained in the validation of the analytical method for each of the buffer solutions tested, the absorbance values of Casiopeina III-Ea were taken at $273 \mathrm{~nm}$ and the pKa was calculated with the following equation, where the $\mathrm{pH}$ value complies with the following relation:

$$
\mathrm{A}=(\mathrm{A} 1+\mathrm{A} 2) / 2 \text {, }
$$

A: Absorbance at which the compound is $50 \%$ in ionized form and $50 \%$ is in its non-ionized form, respectively, $\mathrm{pH}=\mathrm{pKa}$

Where,

A1: Absorbance of the acidic species

A2: Absorbance of the basic species.

\section{Determination of $\log \mathrm{D}$ at $\mathrm{pH} 6.8$ and 7.4}

The coefficient of determination for Casiopeina III-Ea (CasIIIEa) in the $n$-octanol-buffer solution system at different $\mathrm{pH}$ was carried out by the shake-flask technique [14]. Prior to carrying out Log D determination, the organic phase was saturated by placing solution buffer over $n$-octanol, the system was shaken for $5 \mathrm{~min}$ and it was allowed to stand to separate both phases and finally the aqueous phase was discarded. Buffer solution at a concentration of $15 \mu \mathrm{g} / \mathrm{mL}$ of Casiopeina III-Ea at each test $\mathrm{pH}$ and saturated $n$-octanol were tested. Once the phases were separated, the aqueous phase (Casiopeina III-Ea $15 \mathrm{ug} / \mathrm{mL}$ at test $\mathrm{pH}$ ) and the organic phase were collected separately. After the extraction process was completed for three times, the aqueous phase was read at $273 \mathrm{~nm}$ in a UV-Vis spectrophotometer. The data were interpolated in the standard calibration curve ranging from 2.5 to $15 \mu \mathrm{g} / \mathrm{mL}$ at a pH 6.8 and at $\mathrm{pH} 7.4$ solution. The concentration of Casiopeina III-Ea in the organic phase is obtained by difference when knowing its concentration in the aqueous phase. The value of the partition coefficient was calculated using the following formula:

$$
D=\frac{[\text { CasIIIEa }] \text { organic }}{[\text { CasIIIEa }] \text { aqueous } p H \text { tested }}
$$

\section{Intrinsic solubility in buffer solution at pH 6.8 and 7.4}

Intrinsic solubility [15] was determined as follows: amounts of 10 to $1900 \mathrm{mg}$ of Casiopeina III-Ea were added in $10 \mathrm{~mL}$ volumetric flasks and were brought to the level with each phosphate buffer at different $\mathrm{pH}$. The flasks were placed in a water bath with shaking at $37^{\circ} \mathrm{C}$ for $24 \mathrm{~h}$. After the stirring time, it was observed if each flask presented a precipitate, samples were taken and filtered through a $0.45 \mu \mathrm{m}$ nylon filter. The samples were analysed by spectrophotometry at $273 \mathrm{~nm}$ and interpolated in a standard curve $(2.5-15 \mathrm{ug} / \mathrm{mL})$ with a 
previously validated method, solubility was determined to the extent that it was observed that sample concentration no longer increased.

\section{Quantification of Casiopeina III Ea.}

A liquid chromatographic method was developed and validated using Hank's solution, Based on previous chromatographic quantification conditions of unchanged compound Casiopeinas. $[16,17,18]$

An HPLC with a LC10ADVP pump model, a SPD10AD UV variable wave detector, a SIL10ADVP autosampler with a loop from 20 to $100 \mu \mathrm{L}$ (Cotati, CA, USA), and a control system SCL10AVP VP version 5 chromatographic data integrator, 1999, all from Shimadzu (Tokyo, Japan) were used. Also, an Eclipse Plus C-8 column ( $4.6 \times 150 \mathrm{~mm}$ ), $3.5 \mu \mathrm{m}$ (particle size) from Agilent Zorbax, and a guard column with C-18 cartridge from Phenomenex. Mobile phase in 70/30 ratio $0.01 \mathrm{M}$ phosphate buffer $\mathrm{pH}=7.6 /$ methanol, lambda $=273$ $\mathrm{nm}$, flow rate $=0.8 \mathrm{ml} / \mathrm{min}$, injection volume $25 \mu \mathrm{L}$, and sample analysis temperature of $25^{\circ} \mathrm{C}$.

\section{Calibration curve in Hank's solution}

Casiopeina III-Ea $(10 \mathrm{mg})$ was weighed and made up to a volume of $10 \mathrm{~mL}$ with Hank's solution (1000 $\mu \mathrm{g} / \mathrm{mL}$ ); consecutive dilutions were made at a volume of $1 \mathrm{~mL}$ to obtain a concentration range from 1.25 to $20 \mu \mathrm{g} / \mathrm{mL}$. Samples were filtered through a $0.45 \mu \mathrm{m}$ membrane before injecting into HPLC for analysis. For reproducibility, two days of analysis, 3 control points (high, medium and low) were evaluated in six times each day. The linearity was worked with the calibration curve from 1.25 to $20 \mu \mathrm{g} / \mathrm{mL}$ by triplicate in 1 day.

\section{Cytotoxicity study in MDCK (Madin Darby Canine Kidney) cells}

As a complement to the study of permeability in MDCK cells, the study of cytotoxicity in these cells was carried out to provide an idea about the adequate doses to work in these cells.

To evaluate cytotoxicity, the colorimetric method of Sulforhodamine B (SRB) was used in ELISA plates. The plate was divided into quadrants to test the following logarithmic concentrations $(\mu \mathrm{M})$ in six-fold each: $0.22,2.24,22.4,224,2240,11000$ and 22000 for Casiopeina III-Ea. MDCK cells $\left(2 \times 10^{4} /\right.$ well) were seeded in $100 \mu \mathrm{l}$ of supplemented DMEM medium, incubated at $37{ }^{\circ} \mathrm{C}, 5 \% \mathrm{CO}_{2}$ and $95 \% \mathrm{RH}$ for $24 \mathrm{~h}$. Then, the medium was removed and $90 \mu \mathrm{L}$ of fresh medium and $10 \mu \mathrm{L}$ of the solution to be evaluated were added. Cells were further incubated for $24 \mathrm{~h}$. Once the treatment time had elapsed, the medium was removed and the cells were fixed with $100 \mu \mathrm{L}$ of $10 \%$ TCA solution for $1 \mathrm{~h}$, the TCA was discarded, and the cells were washed with water and left to dry. Once dry, the cells were stained with $50 \mu \mathrm{L}$ of $0.4 \%$ SRB solution in acetic acid, the plate was read at a length of $564 \mathrm{~nm}$. The viability or proliferation of the cells is determined by the degree of staining expressed by the absorbance of the wells, which were directly proportional, the greater the number of living cells, the greater the staining and therefore the greater the absorbance. [19, 20]

\section{Results and discussion}

\section{Spectrophotometric method validation}

The linearity and repeatability were determined by means of calibration curves in buffer solution at each test $\mathrm{pH}$ in a range of 2.5 to $15 \mu \mathrm{g} / \mathrm{mL}$ by triplicate, the results are presented in Table 1. (CV\%, Percentage of coefficient of variability). 
Table 1. Determination of the linearity and repeatability of Casiopeina III-Ea solutions at different $\mathrm{pH}$ 's.

\begin{tabular}{|c|c|c|c|c|c|c|c|}
\hline & $\begin{array}{c}\mathrm{pH}=1.2 \\
\text { Mean } \\
\mathrm{n}=3\end{array}$ & $\begin{array}{c}\mathrm{pH}=3.5 \\
\text { Mean } \\
\mathrm{n}=3\end{array}$ & $\begin{array}{c}\mathrm{pH}=4.6 \\
\text { Mean } \\
n=3\end{array}$ & $\begin{array}{c}\mathrm{pH}=\mathbf{5 . 0} \\
\text { Mean } \\
\mathrm{n}=\mathbf{3}\end{array}$ & $\begin{array}{c}\mathrm{pH}=6.8 \\
\text { Mean } \\
\mathrm{n}=3\end{array}$ & $\begin{array}{c}\mathrm{pH}=7.4 \\
\text { Mean } \\
\mathrm{n}=3\end{array}$ & $\begin{array}{c}\mathrm{pH}=8.0 \\
\text { Mean } \\
\mathrm{n}=\mathbf{3}\end{array}$ \\
\hline $\begin{array}{c}\text { Concentration } \\
(2.5-15 \\
\mu \mathrm{g} / \mathrm{mL})\end{array}$ & $\begin{array}{c}\mathrm{CV} \%(0.2 \\
-2)\end{array}$ & $\begin{array}{c}\text { CV\% }(0.2 \\
\quad-1.2)\end{array}$ & $\begin{array}{c}\text { CV\% } \%(0.1 \\
-1.7)\end{array}$ & $\begin{array}{c}\text { CV\% } \%(0.1 \\
-0.6)\end{array}$ & $\begin{array}{c}\text { CV\% } \%(0.1 \\
-1.6)\end{array}$ & $\begin{array}{c}\text { CV\% }(0.1 \\
-0.4)\end{array}$ & $\begin{array}{c}\text { CV\% }(0.1 \\
-0.7)\end{array}$ \\
\hline $\mathbf{r}$ & 0.9995 & 0.9994 & 0.9997 & 0.9998 & 0.9998 & 0.9998 & 0.9998 \\
\hline RSE (\%) & 0.55 & 1.82 & 0.3223 & 0.01 & 0.01 & 0.9133 & 0.01 \\
\hline
\end{tabular}

RSE (\%), regression standard error (\%)

\section{Determination of pKa}

The $\mathrm{pKa}$ of a molecule is a parameter related to the state of its charge, it is a descriptor of the acidbase balance. Casiopeina III-Ea was prepared at a concentration of $10 \mu \mathrm{g} / \mathrm{ml}$, absorbance values were obtained at different $\mathrm{pH}^{\prime} \mathrm{s}$.

To obtain the value of $\mathrm{pKa}, \mathrm{A}=(0.9528+0.8227) / 2, \mathrm{~A}=0.88775$

By means of the regression obtained from the relationship $\mathrm{pH}$ vs absorbance value, the $\mathrm{pH}$ corresponding to $\mathrm{pKa}$ is obtained with the following formula $\mathrm{pH}=(\mathrm{A}-\mathrm{B}) / \mathrm{m}=(0.88775-1.0948) /-0.0413$ resulting in $\mathrm{pH}=5.01$. According to these results, Casiopeina III-Ea behaves as a weak acid conjugated with $\mathrm{pKa}=5.01$, in the form of a nitrate salt, the unionized compound will be the weak base. Therefore, based on these results, as the $\mathrm{pH}$ increases, it is expected to be better absorbed in the intestine. It is expected to be better absorbed as a unionized compound in the intestine. When considering an intravenous route of administration, there will be a $\mathrm{pH}$ of 7.4 in the blood, where it could be observed in terms of the Henderson-Hasselback equation; a higher concentration of the non-ionized compound considered as a weak base, a better distribution in the body will occur. This molecule compared to Casiopeina IIIia (pka $=5.3$ ), for example of $\mathrm{Cu}(2,20-$ bipyridine) (acetylacetonato), and Casiopeina IIgly (pka 5.95), for example of $\mathrm{Cu}$ (1,10- phenanthroline) (glycinato) has a similar pKa value. [8]

\section{Determination of $\log \mathrm{D}$ at $\mathrm{pH} 6.8$ and 7.4}

The determination of the distribution coefficient at different $\mathrm{pH}$ 's was carried out using the shake-flask method. Once the water and n-octanol system reaches equilibrium, an aliquot of the aqueous phase was taken and the concentration of Casiopeina III- Ea was determined. Then by interpolating the absorbance in the previously validated calibration curve in a range of 2.5 to $15 \mu \mathrm{g} / \mathrm{mL}$ and by difference the concentration in the organic phase is established. Table 2 shows the results obtained in the determination of the distribution coefficient for Casiopeina III-Ea at the $\mathrm{pH}$ 's tested.

Table 2. Determination of the distribution coefficient.

\begin{tabular}{|c|c|c|}
\hline \multicolumn{3}{|c|}{ Mean } \\
\hline $\begin{array}{c}\text { Buffer phase concentration Casiopeina } \\
\text { III-Ea } \mu \mathrm{g} / \mathrm{mL}\end{array}$ & $\mathbf{p H ~ 7 . 4}$ & $\mathbf{p H ~ 6 . 8}$ \\
\hline $\begin{array}{c}\text { Organic phase concentration Casiopeina } \\
\text { III-Ea } \mu \mathrm{g} / \mathrm{mL}\end{array}$ & 4.77 & 11.05 \\
\hline Organic phase/buffer phase relation (D) & 0.47 & 0.36 \\
\hline $\log \mathbf{D}$ & $\mathbf{- 0 . 3 3}$ & $\mathbf{- 0 . 4 4}$ \\
\hline
\end{tabular}


Table 2 shows that according to the Log D values obtained at pH 6.8 and 7.4, Casiopeina III-Ea is a molecule with some hydrophilic characteristics (water soluble); thus, its lipophilicity is low. There is a good solubility but low absorption and brain penetration, owing to low passive diffusion permeability, these compounds tend to have high clearence by the kidney, owing to their polarity. May exhibits paracellular permeation if the molecular weight is low. This molecule compared with Casiopeina IIIia $(\log \mathrm{D}=-0.95)$ has a less negative $\log$ D. $[8,21]$

\section{Intrinsic solubility}

In the results obtained for the determination of the intrinsic solubility of Casiopeina III-Ea, this molecule presented a solubility of $180 \mathrm{mg} / \mathrm{mL}$ at $\mathrm{pH} 6.8$ and $170 \mathrm{mg} / \mathrm{ml}$ at $\mathrm{pH} 7.4$. The results have suggested that since it is a weak acid (conjugate), with pKa 5.01, it is soluble at these $\mathrm{pH}^{\prime} \mathrm{s}$.

It was expected that its solubility and the behaviour of the non-ionized form to be higher in lipophilic medium than in aqueous medium (170 mg / mL, at $\mathrm{pH} 7.4)$, above the $\mathrm{pKa}$ of 5.01, but this situation did not happen, it means that Casiopeina III-Ea solubility remains hydrophilic. Good stability of the solution at those pH's, between 4 and 8, was reported, this indicates that the results at $\mathrm{pH} 7.4$ are acceptable. [22]

\section{Validation of the analytical method by HPLC-UV for Casiopeina III-Ea}

Chromatograms shown in Fig. 2 confirm that there are no interferences from the components of Hank's solution for the retention time of Casiopeina III-Ea; therefore, the method is considered selective. The linearity of the method to quantify Casiopeina III-Ea in Hank's solution was obtained in a working range of 1.25 to 20 $\mu \mathrm{g} / \mathrm{mL}$, the average linearity was $0.9971(\mathrm{n}=3)$, the analytical method complies with the linearity parameter, since the correlation coefficient was greater than 0.99 .
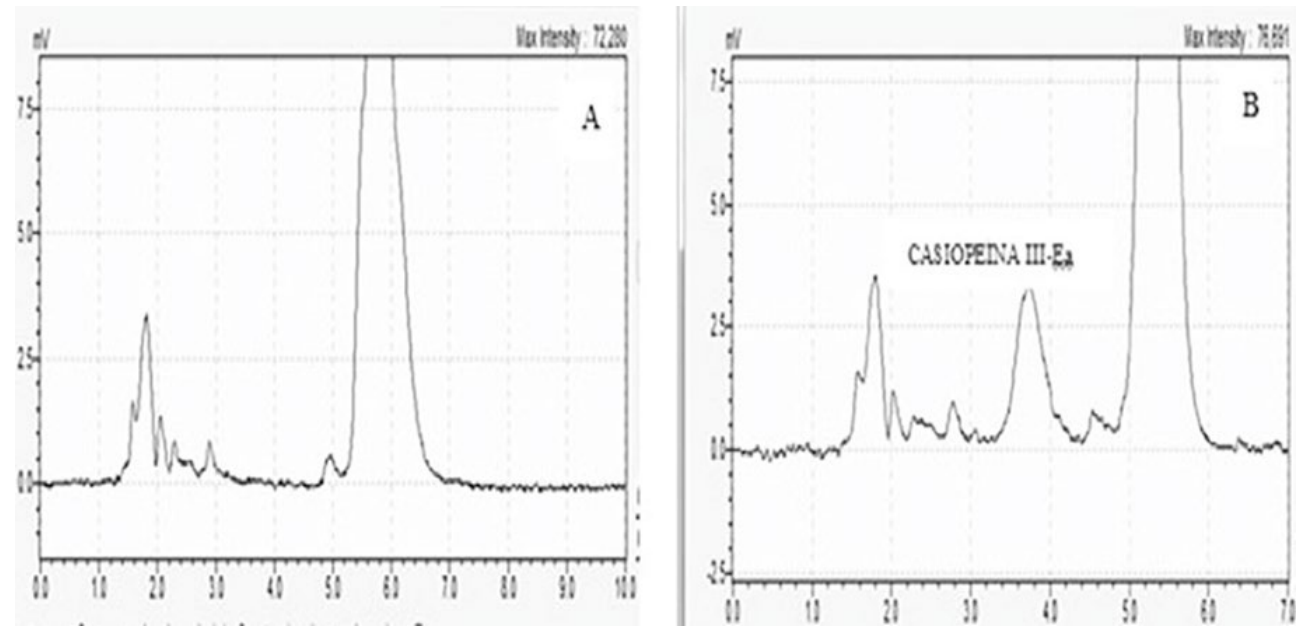

Fig. 2. Chromatogram of Hank's solution (A), chromatogram of Casiopeina III-Ea (B).

The intra-day precision for Casiopeina III-Ea was estimated with Hank's solution calibration curve at the following concentrations: $1.25,2.5,5,10$ and $20 \mu \mathrm{g} / \mathrm{mL}$. The following sextuplicate control points 2 (MCB), 8 (MCM) and 15 (MCA) $\mu \mathrm{g} / \mathrm{mL}$ were used. Table 3 shows the results of precision (CV\%) and accuracy (Abs Dev) for the analytical method. 
Table 3. Precision and accuracy of the method for Casiopeina III-Ea in Hank's solution.

\begin{tabular}{|c|c|c|c|c|c|c|}
\hline \multirow{2}{*}{} & \multicolumn{2}{|c|}{$\mathbf{\mu g} / \mathbf{m L}$} & \multicolumn{2}{c|}{$\mathbf{8 \mu g} / \mathbf{m L}$} & \multicolumn{2}{c|}{$\mathbf{1 5} \boldsymbol{\mu g} / \mathbf{m L}$} \\
\cline { 2 - 7 } & $\mathbf{C V} \%$ & Abs Dev \% & CV\% & Abs Dev \% & CV\% & Abs Dev \% \\
\hline Mean n=6 & 10.58 & 5.34 & 5.26 & 4.63 & 5.91 & 4.99 \\
\hline
\end{tabular}

The CV\% and accuracy are less than $15 \%$ at each concentration level $(2,8$ and $15 \mu \mathrm{g} / \mathrm{mL})$, the accuracy values are less than $15 \%$ with respect to the nominal value, therefore, the results showed that the analytical method meets the parameters of precision and accuracy.

\section{Cytotoxicity study in MDCK cells}

The cytotoxicity at different concentrations of Casiopeina III-Ea, was obtained in the MCDK cell line, it is shown in Fig. 3. The data for the $\mathrm{IC}_{50}$ determination was adjusted using a sigmoidal equation, the determination coefficient $\left(\mathrm{r}^{2}\right)$ was 0.97, using GraphPad Prisma Statistical Program. The $\mathrm{IC}_{50}$ was 19.07 $\mu \mathrm{M} \pm 7.1$.

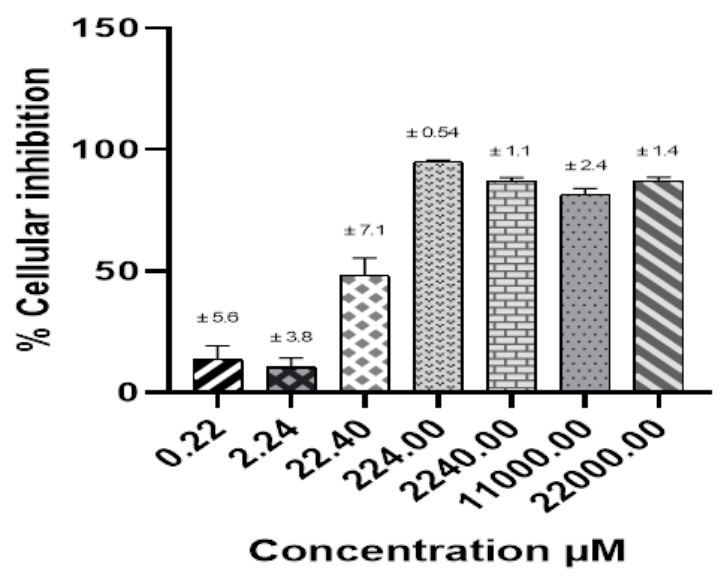

Fig. 3. \% Inhibition of cell growth by Casiopeina III-Ea at different concentrations, with standard deviation.

According to the graph obtained in the cytotoxicity study (Fig. 4), it is observed that to be able to inhibit cell proliferation at $50 \%\left(\mathrm{IC}_{50}=19.07 \mu \mathrm{M}\right)$ higher concentrations are needed in MDCK cells in comparison with those reported with other tumor cell lines as HCT-15 ( IC $50=4.6 \mu \mathrm{M}$ ), Hela $\left(\mathrm{IC}_{50}=1.4\right.$ $\mu \mathrm{M})$, SiHa $\left(\mathrm{IC}_{50}=0.96 \mu \mathrm{M}\right)[8]$ y CHIP-212 $(18.68 \mu \mathrm{M})$ [2]. For this reason, concentrations below the $\mathrm{IC}_{50}$ determined for Casiopeina III-Ea can be used without compromising cell proliferation for permeability studies $[19,20]$.

Within the studies of Casiopeinas, this study represents the first one in MDCK cells in order to apply them into permeability studies and within the coordination molecules with metals, they have not yet been reported. 


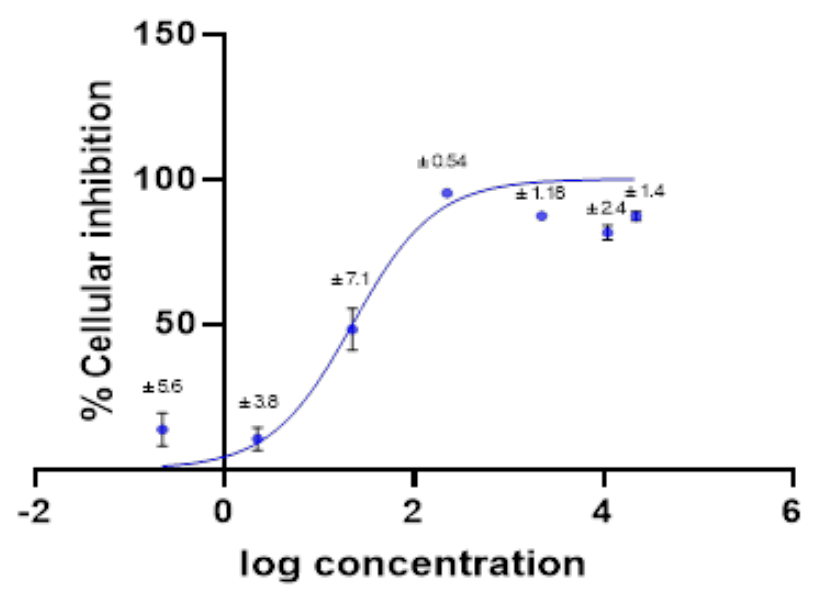

Fig. 4. Casiopeina III-Ea $\mathrm{IC}_{50}$ determination against MDCK cells.

\section{Conclusion}

Casiopeina III-Ea molecule behaves as a weak conjugated acid, ionized as a nitrate, bearing a $\mathrm{pKa}=5.01$ and became hydrophilic. The physicochemical parameters of $\mathrm{pKa}$, distribution coefficient and intrinsic solubility, are thermodynamic constants which help to understand the behaviour of Casiopeina III-Ea in the body, in addition to the fact that the molecule complies with some Lipinski rules: less than 5 hydrogen bond donors, molecular mass less than 500 Dalton and less than 10 hydrogen bond acceptors. Considering the $\mathrm{IC}_{50}$ for MDCK cells $19.07 \mu \mathrm{M}$, and the molecular weight of Casiopeina III-Ea, (450.94 g / mol), MDCK cells remain alive to perform permeability studies with doses of $8.56 \mathrm{mg}$.

These findings help us, to qualify Casiopeina III-Ea as a new promising antileukemic activity, taking the advantages of their satisfying physicochemical properties that lie within the acceptable range of the $90 \%$ known drugs. However, in vitro permeability studies and preclinical pharmacokinetic studies are recommended to perform better understanding of the bioavailability of Casiopeina III-Ea. To date, coordination compounds with metals are gaining popularity, but studies based on physicochemical and biopharmaceutical properties for their optimization as therapeutic molecules have not been reported.

\section{Acknowledgements}

This work was financially supported by DGAPA, PAPIIT IN 221118, UNAM. We are also grateful to M. in C. Francisco Sánchez Bartéz, UNEXA, Chemistry Faculty UNAM who supported us with the MDCK cells.

Thanks to Fabiola Nieto Camacho for proofreading.

\section{References}

1. Ruiz-Azuara, L.; Bravo-Gómez, M.E. Curr. Med. Chem. 2010, 17, 3606-3615. DOI: $10.2174 / 092986710793213751$ 
2. Gutiérrez, A. G.; Vázquez-Aguirre, A.; García-Ramos, J.C.; Flores-Alamo, M.; Hernández-Lemus, E.; Ruiz-Azuara, L.; Mejía, C. J. Inorg. Biochem. 2013, 126, 17-25. DOI: 10.1016/j.jinorgbio.2013.05.001

3. Vidal, L.M.; Pimentel, E.; Cruces, M.P.; Hernández, S.; Ruiz-Azuara, L. J. Toxicol. Environ. Eealth, part A. 2017, 80, 365-373. DOI: 10.1080/15287394.2017.1326072

4. Rivero-Müller, R.; De Vizcaya-Ruiz, A.; Plant, N.; Ruiz-Azuara, L.; Dobrota M. Chem. Biol. Interact. 2007, 165, 189-199. DOI: 10.1016/j.cbi.2006.12.002

5. Alemón-Medina, R.; Brena-Valle, M.; Muñoz-Sánchez, J. L.; Gracia-Mora, M. I.; Ruiz-Azuara, L. Cancer Chemother. Pharmacol. 2007, 60, 219-228. DOI: 10.1007/s00280-006-0364-9

6. Mejía, C.; Ruiz-Azuara, L. Pathol. Oncol. Res. 2008, 14, 467-472. DOI: 10.1007/s12253-008-9060-x

7. Trejo-Solís, C.; Palencia, G.; Zúñiga, S.; Rodríguez-Ropon, A.; Osorio-Rico, L.; Sanchez Torres, L.; Gracia-Mora, I.; Marquez-Rosado, L.; Sánchez, A.; Moreno-García, M. E.; Cruz, A.; Bravo-Gómez, M. E.; Ruiz-Ramírez, L.; Rodríguez-Enriquez, S.; Sotelo, J. Neoplasia. 2005, 7, 563-574. DOI: $10.1593 /$ neo.04607

8. Bravo-Gómez, M. E.; García-Ramos, J. C.; Gracia-Mora, I.; Ruiz-Azuara, L. J. Inorg. Biochem. 2009, 103, 299-309. DOI: 10.1016/j.jinorgbio.2008.10.006

9. Skehan, P.; Storeng, R.; Scudiero, D.; Monks, A.; McMahon, J.; Vistica, D.; Warren, J.T., Bokesch, H.; Kenney, S.; Boyd, M.R. J. Natl. Cancer Inst. 1990, 82, 1107-1112. DOI: 10.1093/jnci/82.13.1107

10. Vértiz, G.; García-Ortuño, L. E.; Bernal, J. P.; Bravo-Gómez, M. E.; Lounejeva, E.; Huerta, A.; RuizAzuara, L. Fundam. Clin. Pharmacol. 2014, 28,78-87. DOI: 10.1111/j.1472-8206.2012. 01075.x

11. García-Ramos, J. C.; Galindo-Murillo, R.; Tovar-Tovar, A.; Alonso-Saenz, A. L.; Gómez-Vidales, V.; Flores-Alamo, M.; Ortiz-Frade, L.; Cortes-Guzmán, F.; Moreno-Esparza, R.; Campero, A.; RuizAzuara, L. Chem. Eur. J. 2014, 20, 13730-13741. DOI: 10.1002/chem.201402775

12. Chavez-Gonzalez, A.; Centeno-Llanosa, S.; Moreno-Lorenzana, D.; Sandoval-Esquivela, M. A.; Aviles-Vazquez, S.; Bravo-Gómez, M. E.; Ruiz-Azuara, L.; Ayala-Sanchez, M.; Torres-Martineze, H.; Mayania, H. Leuk. Res. 2017, 52, 8-19. DOI: https://doi.org/10.1016/j.leukres.2016.11.001

13. Guidance for Industry Statistical Approaches to Establishing Bioequivalence, U.S. Department of Health and Human Services Food and Drug Administration Center for Drug Evaluation and Research (CDER),

2001,

$1-48$. https://ntrl.ntis.gov/NTRL/dashboard/searchResults/titleDetail/PB2010104191.xhtml

14. Takács-Nova'k, K.; Avdeef, A. J. Pharm. Biomed. Anal. 1996, 14, 1405-1413. DOI: 359 https://doi.org/10.1016/0731-7085(96)01773-6

15. Yalkowskv, S.H.; Valvani, S.C.; Mackay, D. Residue Rev. 1983, 85, 43-55. DOI:10.1007/978-1-4612361 5462-1_5.

16. Reyes, L.; Fuentes-Noriega, I.; Ruiz-Ramírez, L.; Macías, L. J. Chromatogr. B. 2003, 791, 111-116. DOI: $10.1016 / \mathrm{s} 1570-0232(03) 00226-5$

17. Fuentes-Noriega, I.; Ruiz-Ramírez, L.; Tovar Tovar, A.; Rico-Morales, H.; Gracia-Mora, I., J. Chromatogr. B. 2002, 772, 115-121. DOI: https://doi.org/10.1016/S1570- 0232(02)00064-8

18. Cañas, A. R. C., Fuentes-Noriega, I.; Ruiz-Azuara, L. J. Bioanal. Biomed. 2010, 2, 28-34. DOI: 10.4172/1948-593X.1000018

19. Comer, J.E.A. High throughput measurement of $\log D$ and $p K a$. In P. Artursson, H. Lennernas \& H. van de Waterbeemd (Eds.) Methods and principles in medicinal chemistry 18, Weinheim Wilet-VCH, 2003, 21-45.

20. Riss, T.; Niles, A.; Moravec, R.; Karassina N.; Vidugiriene, J. Sciences 2019, 1-15. https://www.ncbi.nlm.nih.gov/books/NBK540958/(visited January 23, 2021). 
21. Niles, A. L.; Moravec, R. A.; Riss, T.L. Expert Opin Drug Discov. 2008, 3, 655-669. DOI: 10.1517/17460441.3.6.655

22. Diaz, J. Casiopeinas stability at different pH's. Bachelor thesis. Faculty of Chemistry. UNAM. In preparation. 